\title{
Movement patterns of goliath grouper Epinephelus itajara around southeast Cuba: implications for conservation
}

\author{
F. Pina-Amargós ${ }^{1, *}$, G. González-Sansón ${ }^{2}$ \\ ${ }^{1}$ Centro de Investigaciones de Ecosistemas Costeros, Cayo Coco, Morón, Ciego de Ávila, CP 69 400, Cuba \\ ${ }^{2}$ Centro de Investigaciones Marinas, Calle 16 No. 118 entre 1ra y 3ra, Ciudad de la Habana, Cuba
}

\begin{abstract}
Goliath grouper Epinephelus itajara is the largest grouper in the western hemisphere. Recently, populations have experienced dramatic declines that have become a major cause of concern for scientists and conservationists. It is essential for conservationists and managers to understand the species' movement patterns if marine protected areas are to be effectively designed. We present results of goliath grouper movements following conventional tagging within and adjacent to the Jardines de la Reina Archipelago, which includes the Caribbean's largest marine reserve. Five individuals were tagged in 2001 and tracked until 2003, with 541 underwater resightings through summer 2002 at the tagging sites. No goliath grouper were resighted after July 2002 at Jardines de la Reina diving sites. In February 2002, 1 individual was caught $36 \mathrm{~km}$ northeast of the tagging site. In August 2002, a second tagged specimen was caught $77 \mathrm{~km}$ southeast of the tagging site, while in August 2003, 2 individuals were captured $168 \mathrm{~km}$ southeast of the tagging site, at a possible spawning aggregation site. All recaptures took place outside reserve boundaries. We assess these findings and their implications for goliath grouper conservation in Cuba.
\end{abstract}

KEY WORDS: Goliath grouper · Epinephelus itajara · Tag-recapture · Conservation · Marine protected areas

Resale or republication not permitted without written consent of the publisher

\section{INTRODUCTION}

Goliath grouper Epinephelus itajara is the largest grouper in the western hemisphere and one of the 2 largest groupers in the world, growing to $250 \mathrm{~cm}$ in total length (TL) (Heemstra \& Randall 1993) and with a maximum weight of $320 \mathrm{~kg}$ (Smith 1971). Goliath grouper is a long-lived species (at least $37 \mathrm{yr}$ ) and reaches maturity at 6 to $7 \mathrm{yr}$ (120 to $135 \mathrm{~cm} \mathrm{TL}$ ) for females and 4 to $6 \mathrm{yr}$ (110 to $115 \mathrm{~cm}$ TL) for males (Bullock et al. 1992). The species makes ontogenetic, seasonal and spawning migrations (Coleman et al. 2000) and forms relatively small (10 to 100 ind.) spatially and temporally predictable spawning aggregations (Sadovy \& Eklund 1999). Both adults and juvenile goliath grouper show high site fidelity (Eklund \& Schull 2001). Based on data from other grouper species, the natural mortality of goliath grouper is considered low and assumed to be 0.15 (GMFMC 1990). These combined features make goliath grouper particularly susceptible to overexploitation. Once relatively abundant through its distributional range, goliath grouper populations began to decline in the 1960s, undoubtedly a consequence of both intensive spawning aggregation fishing and spearfishing on unwary adults (Sadovy \& Eklund 1999). As a result, the goliath grouper is now overexploited and rarely observed (Sadovy \& Eklund 1999). In the USA, population declines led to a fishery closure and catch moratorium in 1990 in all territorial waters (GMFMC 1990, SAFMC 1990). Internationally, goliath grouper is listed as Critically Endangered by the International Union for Conservation of Nature (Hudson \& Mace 1996).

Besides its economic importance, goliath grouper is presumed to have a high ecological significance in struc- 
turing reef invertebrate and small fish populations, and its removal from the reef community may have negative effects on the food web structure and local prey densities (Sadovy \& Eklund 1999). The role that juvenile goliath grouper play in mangrove habitats is likewise unknown (Sadovy \& Eklund 1999).

Despite its potential importance, little is known about the life cycle of this species. Particularly important for management is an understanding of the species movement patterns, especially in relation to spawning migrations, which have reached $153 \mathrm{~km}$ (Eklund \& Schull 2001) and likely involve movement outside protected areas. Currently, most spawning aggregation sites for goliath grouper are either unknown to managers, or are unreported or unprotected (Sadovy \& Eklund 1999).

The main goals of the present study were to assess goliath grouper site fidelity and movement patterns relative to tagging locations in the Jardines de la Reina Marine Reserve and National Park (JRMRNP) and at presumed spawning aggregation sites outside of the protected area. We discuss the implications of these findings for conservation and management of this species in the study area.

\section{MATERIALS AND METHODS}

Study area. The Jardines de la Reina Archipelago stretches $360 \mathrm{~km}$ from the Gulf of Guacanayabo to Casilda Bay, south of Cuba, and is comprised of 661 keys (Fig. 1). Since 1996, about $950 \mathrm{~km}^{2}$ of Jardines de

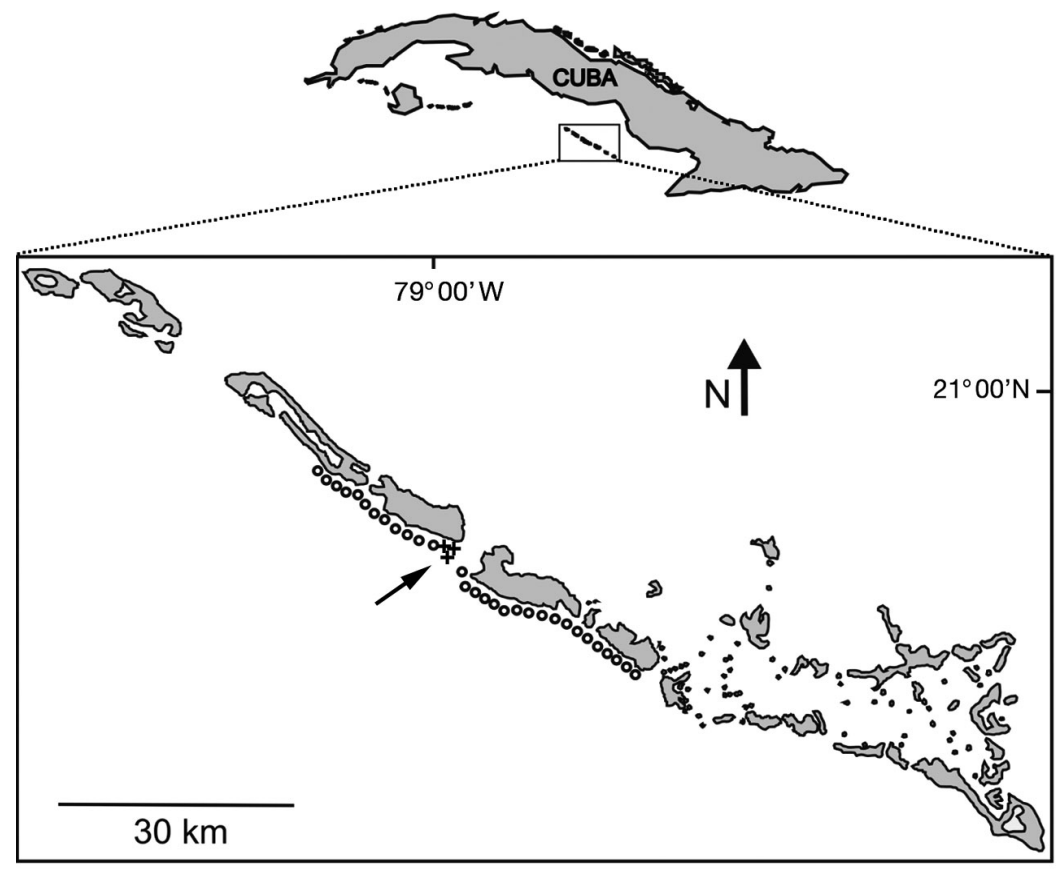

Fig. 1. Study area, Jardines de la Reina Archipelago, Cuba. o: places where tourist diving takes place; surveys for tagged goliath grouper were made regularly at these sites. +: tagging sites (arrowed) la Reina have been recognized as a Zone Under Special Regime of Use and Protection (ZUSRUP), according to the Ministry of Fisheries Resolution 562/96. This Cuban natural protected areas system category is equivalent to a marine reserve. The entire archipelago has been proposed as a national park (about $3000 \mathrm{~km}^{2}$ ) and is pending approval by the Cuban government. Jardines de la Reina has substantial red mangrove coverage and reef habitats with plenty of caves, overhangs and other habitat critical for goliath grouper across different life history stages.

Survey methods. Surveys were undertaken as part of tourist diving operations based in Jardines de la Reina (Azulmar fishing/diving company). Tagging was carried out in January and August 2001, south of the easternmost end of Cayo Caballones $\left(20^{\circ} 49^{\prime} 50^{\prime \prime} \mathrm{N}\right.$, $78^{\circ} 59^{\prime} 05^{\prime \prime} \mathrm{W}$ ) at 3 dive sites less than $300 \mathrm{~m}$ apart and with frequent sightings of goliath grouper (Fig. 1). Goliath grouper were tagged underwater $(n=5)$ using SCUBA with dart tags (Floy Tag FT-1-94) employing modified spearguns (Starr et al. 2007). Divers (3 Azulmar divemasters and 1 author) tagged all goliath grouper observed during dives, and each diver was trained to identify tagged individuals during the surveys. Tag positions and fish size, color pattern and distinguishing body characteristics were recorded during tagging (to aid individual identification) and resighting. This research was conducted in accordance with institutional, national and international guidelines concerning the use of endangered species in research.

Resightings were made from January 2001 to July 2002 by underwater visual censuses (UVC) at the 3 tagging sites (Cayo Caballones) and at the other 29 Azulmar dive sites, which stretched from $10 \mathrm{~km}$ west to $20 \mathrm{~km}$ east of the tagging sites (Fig. 1). Surveys were conducted primarily at tourist dive sites to take advantage of the dive centers assistance with dive logistics. One of the tagging sites accounted for $11.7 \%$ of the surveys (1213 total surveys), while the other 2 tagging sites and 12 no-tagging sites each accounted for 5.3 to $6.3 \%$ of the total UVC surveys conducted. UVCs at the remaining sites accounted for less than $1 \%$ of the total surveys. UVCs were based on opportunistic roving diver methodology conducted on coral reefs from 8 to $30 \mathrm{~m}$ depth, at 3 different diving sites daily for $6 \mathrm{~d}$ per week over the 18 mo project. Visibility during UVCs always exceeded $20 \mathrm{~m}$. Diving activities in Jardines de la Reina were not inter- 
rupted or prevented by bad weather in the course of the survey. No night dives were conducted. Recapture data from fishermen were obtained until August 2003.

The frequency of resightings was defined as follows:

$$
F=[(\mathrm{RTS} / \mathrm{STS}) / N] 100
$$

where $F$ is the frequency of resightings, RTS the number of resightings at tagging sites, STS the number of surveys at tagging sites and $N$ the accumulated number of specimens tagged.

\section{RESULTS}

There were 545 resightings of the 5 tagged goliath groupers, including the 4 individuals recaptured by fishermen. All resightings took place at the tagging sites (Table 1). The frequency of resighting was high ( $>50 \%$ for the entire study period) with increased resightings as sample size increased. Individual movements averaged $93 \pm 5 \mathrm{~m}( \pm \mathrm{SE})$ for specimens resighted through UVC.

All 4 individuals recaptured by fishermen were taken outside JRMRNP boundaries. A $100 \mathrm{~cm}$ individual tagged in August 2001 was resighted at the tagging sites approx. 20 times monthly in August 2001, December 2001 and January 2002 prior to capture in February 2002 at Cayo Chocolate $\left(20^{\circ} 50^{\prime} 28^{\prime \prime} \mathrm{N}\right.$, $\left.78^{\circ} 37^{\prime} 52^{\prime \prime} \mathrm{W}\right)$, about $36 \mathrm{~km}$ away from the tagging

Table 1. Epinephelus itajara. Summary of tagging, resightings, survey effort and frequency of resightings of goliath grouper individuals. $N$ : accumulated number of specimens tagged; RTS: number of resightings at tagging sites; STS: number of surveys at tagging sites; $F$ : frequency of resightings; RNTS: number of resightings at no-tagging sites; SNTS: number of surveys at no-tagging sites

\begin{tabular}{|lcccccc|}
\hline Month & $N$ & RTS & STS & $F$ & RNTS & SNTS \\
\hline $\mathbf{2 0 0 1}$ & & & & & & \\
January & 1 & 11 & 20 & 55 & 0 & 57 \\
February & 1 & 17 & 28 & 61 & 0 & 48 \\
March & 1 & 9 & 15 & 60 & 0 & 60 \\
April & 1 & 15 & 24 & 63 & 0 & 50 \\
May & 1 & 10 & 17 & 59 & 0 & 62 \\
June & 1 & 16 & 25 & 64 & 0 & 52 \\
July & 1 & 12 & 19 & 63 & 0 & 57 \\
August & 5 & 105 & 22 & 95 & 0 & 55 \\
December & 5 & 64 & 16 & 80 & 0 & 59 \\
2002 & & & & & & \\
January & 5 & 59 & 15 & 79 & 0 & 60 \\
February & 4 & 38 & 13 & 73 & 0 & 62 \\
March & 4 & 36 & 12 & 75 & 0 & 65 \\
April & 4 & 37 & 14 & 66 & 0 & 63 \\
May & 4 & 43 & 16 & 67 & 0 & 59 \\
June & 4 & 35 & 13 & 67 & 0 & 62 \\
July & 4 & 34 & 13 & 65 & 0 & 60 \\
Total & - & 541 & 282 & - & 0 & 931 \\
\hline
\end{tabular}

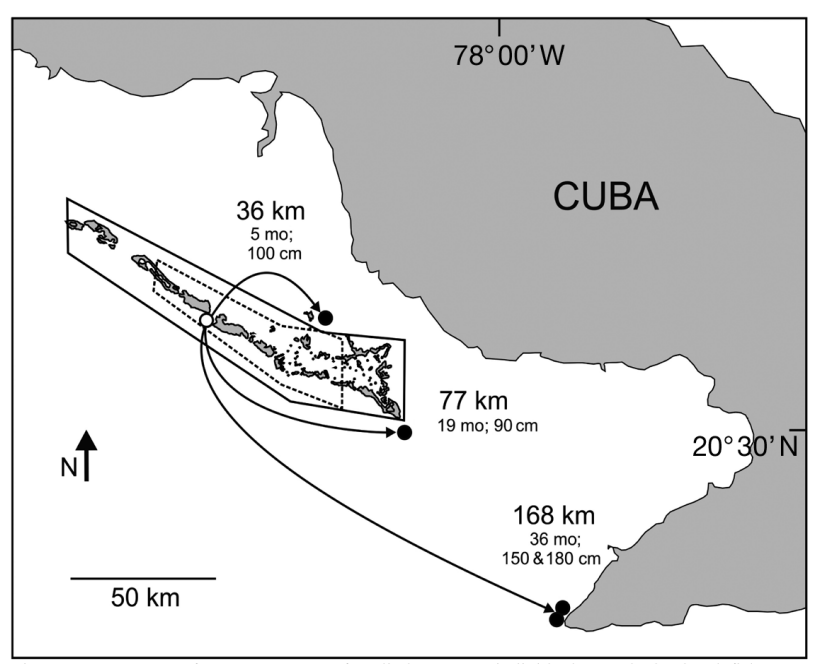

Fig. 2. Epinephelus itajara. Summary of movement of goliath grouper individuals caught by local fishermen outside Jardines de la Reina Marine Reserve and National Park. Arrows are curved just to clarify the diagram. Linear distance between tagging (white circle) and capture sites (black circles), time elapsed and total estimated length of fish are given. Solid line polygon shows the limits of the national park. Dashed line polygon shows the limits of the marine reserve

sites (Fig. 2). A $90 \mathrm{~cm}$ individual, tagged on January 2001, was resighted at the tagging sites approx. 10 times monthly between January and August 2001 and December 2001 and July 2002 prior to capture in August 2002 at Cabeza del Este $\left(20^{\circ} 30^{\prime} 46^{\prime \prime} \mathrm{N}\right.$, $\left.78^{\circ} 19^{\prime} 06^{\prime \prime} \mathrm{W}\right)$, about $77 \mathrm{~km}$ away from the tagging sites (Fig. 2). A $180 \mathrm{~cm}$ and a $150 \mathrm{~cm}$ individual tagged on August 2001 were both resighted at the tagging sites approx. 10 times monthly in August 2001 and between December 2001 and July 2002, and later captured after 24 mo at liberty by the fishery at Cabo Cruz $\left(19^{\circ} 50^{\prime} 28^{\prime \prime} \mathrm{N}, 77^{\circ} 45^{\prime} 07^{\prime \prime} \mathrm{W}\right)$, about $168 \mathrm{~km}$ away from the tagging sites (Fig. 2). The remaining tagged individual, a $120 \mathrm{~cm}$ specimen, was resighted only about 30 times in August 2001 at the tagging site following initial tagging.

\section{DISCUSSION}

Eklund \& Schull (2001) used a step-wise conventional acoustic tagging approach to reveal that juvenile goliath grouper show high site fidelity to their homemangrove, while a few individuals (close to maturity size) moved further (approx. $32 \mathrm{~km}$ ). Similarly, adults showed home-reef and home-mangrove site fidelity, but several specimens tagged offshore at aggregation sites were later recaptured inshore along mangrove and thus demonstrated reproductive migration distances of up to $153 \mathrm{~km}$. Results from the present study 
are in agreement with previous reports of site fidelity and periodic long-distance movement by goliath grouper. The long-distance movements $(77$ and $168 \mathrm{~km}$ ) observed may reflect spawning migrations, since the fish were captured in August at 2 sites reported as spawning aggregation sites by local fishermen (Cabeza del Este and Cabo Cruz; S. Figueredo Díaz pers. comm.). Fishermen at the Cabo Cruz site typically land about 20 goliath groupers annually using spears during the presumed peak reproductive period in Cuba (between August and September; S. Figueredo Díaz pers. comm.). Goliath grouper aggregations numbering in the 10 s to 100 s of individuals have been recorded between June and October in Belize, southeast and southwest Florida and Colombia (Sadovy \& Eklund 1999). Specifically, 24 goliath grouper were recorded aggregating in shallow waters (5 m depth) in Florida (GMFMC 1990), 50 to 60 individuals formed an aggregation off Belize City (Domeier \& Colin 1997) and about 20 to 150 large goliath groupers (45 to $200 \mathrm{~kg}$ ) were reported from southwest Florida (Smith 1976, Sadovy \& Eklund 1999). The aggregation in Belize no longer appears to form following aggregation overfishing. Although actual spawning has not been observed, these occurrences are presumed to represent spawning aggregations (Sadovy \& Eklund 1999). Claro \& Lindeman (2003) reported 21 spawning aggregation sites for snappers and groupers on the Cuban shelf, including the Cabo Cruz site, but none of these are reported sites for goliath grouper.

Although we cannot conclusively demonstrate that the observed long-distance movements of goliath groupers are reproductive, we suggest that this species probably has a relatively small home range fully within the JRMRNP boundaries with periodic migrations outside the protected area where they are highly vulnerable to fishing.

The fact that 4 tagged goliath grouper migrated out of the JRMRNP has very important implications for the species' conservation and management. Marine reserves can protect both juveniles and adults and, if properly placed and adequately sized, the critical habitats on which they may depend (Sadovy \& Eklund 1999, Coleman et al. 2000). Although no spawning aggregations have been recorded for this species in Cuba, anecdotal evidence suggests at least one exists near Cabo Cruz, which is actively fished and located outside JRMRNP boundaries. Thus, despite the protection afforded juveniles and adults by the JRMRNP, individuals obviously remain susceptible to depletion during migrations. We suggest undertaking a study of the Cabeza del Este and Cabo Cruz sites to establish whether these host goliath grouper spawning aggregations. If spawning aggregation sites are identified, 2 management approaches could be implemented to effect this species' conservation. The first approach would entail protecting the spawning aggregation sites by means of catch moratoria and gear restrictions; the second would require the creation of small or medium-sized marine protected areas (MPAs) that contain the spawning aggregation sites and migratory corridors in conjunction with other already established MPAs protecting non-spawning grouper habitat (e.g. JRMRNP). For Cuba, the second approach is more feasible from the socioeconomic viewpoint and would complement the JRMRNP's role in goliath grouper conservation.

Acknowledgements. The authors thank the staff of Azulmar for logistical support on Jardines de la Reina, especially G. Omegna (Pepe). We are also grateful to WWF Canada for funding this research. We thank the Ministry of Science, Technology and Environment for funds and logistics, particularly C. Pazos Alberdi, R. Gómez Fernández and R. Estrada Estrada, and the Ministry of Fisheries for logistics, especially J. Baisre, M. Iglesias (Gallega), Nachi and his crew. Infinite thanks also to CIEC's staff for supporting our research on Jardines de la Reina, especially to T. Figueredo Martín, P. E. Cardoso Gómez and V. O. Rodríguez Cárdenas.

\section{LITERATURE CITED}

Bullock LH, Murphy D, Godcharles MF, Mitchell ME (1992) Age, growth, and reproduction of jewfish Epinephelus itajara in the eastern Gulf of Mexico. Fish Bull 90:243-249

Claro R, Lindeman KC (2003) Spawning aggregation sites of snapper and grouper species (Lutjanidae and Serranidae) on the insular shelf of Cuba. Gulf Carib Res 14:91-106

Coleman FC, Koenig CC, Huntsman GR, Musick JA and others (2000) Long-lived reef fishes: the grouper-snapper complex. Fisheries 25:14-21

Domeier ML, Colin PL (1997) Tropical reef fish spawning aggregations: defined and reviewed. Bull Mar Sci 60:698-726

Eklund AM, Schull J (2001) A stepwise approach to investigating the movement patterns and habitat utilization of goliath grouper, Epinephelus itajara, using conventional tagging, acoustic telemetry and satellite tracking. In: Sibert JR, Nielsen JL (eds) electronic tagging and tracking in marine fisheries. Kluwer Academic Publishers, Dordrecht, p 189-216

GMFMC (Gulf of Mexico Fishery Management Council) (1990) Amendment Number 2 to the Fishery Management Plan for the Reef Fish Fishery of the Gulf of Mexico. GMFMC, Tampa, FL

Heemstra PC, Randall JE (1993) FAO species catalogue. Vol. 16. Groupers of the world (Family Serranidae, Subfamily Epinephelinae). An annotated and illustrated catalogue of the grouper, rockcod, hind, coral grouper and lyretail species known to date. FAO Fisheries Synopsis no. 125, FAO, Rome

Hudson E, Mace G (1996) Marine fish and the IUCN Red List of threatened animals. In: Hudson E, Mace G (eds) Report of the workshop held in collaboration with WWF and IUCN at the Zoological Society of London, 29 April-1 May 1996, Institute of Zoology, London

Sadovy Y, Eklund A (1999) Synopsis of biological data on Nassau grouper, Epinephelus striatus (Bloch 1792), and 
the jewfish, E. itajara (Lichtenstein 1822). NOAA Tech Rep NMFS 146. US Dept Commerce, Seattle, WA SAFMC (South Atlantic Fishery Management Council) (1990) Amendment number 2, regulatory impact review, regulatory flexibility analysis and environmental assessment for fishery management plan for the snapper grouper fishery of the South Atlantic region. SAFMC, Charleston, SC Smith CL (1971) A revision of the American groupers: Epineph-

Editorial responsibility: Kevin Rhodes, Hilo, Hawaii, USA elus and allied genera. Bull Am Mus Nat Hist 146:69-241 Smith GB (1976) Ecology and distribution of eastern Gulf of Mexico reef fishes. Florida Marine Research Publication No. 19, Florida Department of Natural Resources, St. Petersburg, FL

Starr RM, Sala E, Ballesteros E, Zabala M (2007) Spatial dynamics of the Nassau grouper Epinephelus striatus in a Caribbean atoll. Mar Ecol Prog Ser 343:239-249

Submitted: February 20, 2008; Accepted: March 3, 2009 Proofs received from author(s): June 29, 2009 